Article

\title{
Optimization of Hydrogen Peroxide Detection for a Methyl Mercaptan Biosensor
}

\author{
Zhan-Hong Li ${ }^{1,2}$, Houssemeddine Guedri ${ }^{2}$, Bruno Viguier ${ }^{2}$, Shi-Gang Sun ${ }^{1}$ and \\ Jean-Louis Marty ${ }^{2, *}$
}

1 State Key Laboratory of Physical Chemistry of Solid Surfaces, and Department of Chemistry, College of Chemistry and Chemical Engineering, Xiamen University, Xiamen 361005, China; E-Mails: 1zh1508@gmail.com (Z.-H.L.); sgsun@xmu.edu.cn (S.-G.S.)

2 Laboratoire IMAGES EA 4218, Groupe Biocapteurs, Université de Perpignan Via Domitia (UPVD), Bâtiment S, 52 av Paul Alduy 66860 Perpignan Cedex, France;

E-Mails: houssemeddine.guedri@live.fr (H.G.); viguierbr@gmail.com (B.V.)

* Author to whom correspondence should be addressed; E-Mail: jlmarty@univ-perp.fr;

Tel.: +33-4-6866-2254; Fax: +33-4-6866-2223.

Received: 11 March 2013; in revised form: 3 April 2013 / Accepted: 7 April 2013 /

Published: 15 April 2013

\begin{abstract}
Several kinds of modified carbon screen printed electrodes (CSPEs) for amperometric detection of hydrogen peroxide $\left(\mathrm{H}_{2} \mathrm{O}_{2}\right)$ are presented in order to propose a methyl mercaptan (MM) biosensor. Unmodified, carbon nanotubes (CNTs), cobalt phthalocyanine (CoPC), Prussian blue (PB), and Os-wired HRP modified CSPE sensors were fabricated and tested to detect $\mathrm{H}_{2} \mathrm{O}_{2}$, applying a potential of $+0.6 \mathrm{~V},+0.6 \mathrm{~V},+0.4 \mathrm{~V}$, $-0.2 \mathrm{~V}$ and $-0.1 \mathrm{~V}$ (versus $\mathrm{Ag} / \mathrm{AgCl}$ ), respectively. The limits of detection of these electrodes for $\mathrm{H}_{2} \mathrm{O}_{2}$ were $3.1 \mu \mathrm{M}, 1.3 \mu \mathrm{M}, 71 \mathrm{nM}, 1.3 \mu \mathrm{M}, 13.7 \mathrm{nM}$, respectively. The results demonstrated that the Os-wired HRP modified CSPEs gives the lowest limit of detection (LOD) for $\mathrm{H}_{2} \mathrm{O}_{2}$ at a working potential as low as $-0.1 \mathrm{~V}$. Os-wired HRP is the optimum choice for establishment of a MM biosensor and gives a detection limit of $0.5 \mu \mathrm{M}$.
\end{abstract}

Keywords: methyl mercaptan; hydrogen peroxide; amperometric sensor; screen printed electrode 


\section{Introduction}

Methyl mercaptan (MM) is one of the volatile sulfur compounds (VSCs), which are known to be involved in halitosis (bad breath) [1,2] and periodontal diseases [2], and the predominant causative factor of noticeable oral malodor [3]. MM is also present in several other cases such as the bottle storage of wines [4]; wood-pulp mills, sewage treatment plants and factories producing jet fuel, pesticides and plastics [5]; and even in the atmosphere and on the ocean surface [6]. Consequently, MM detection is important in the dental, medical, food, environment and atmosphere fields.

A low-cost, sensitive and specific sensor for detecting MM could be an interesting alternative to conventional MM monitoring methods such as the use of a halimeter, an expensive device, in the dental field [7,8]. Biosensors to monitor MM have been described by Mitsubayashi et al. [9-12]. In their work, monoamine oxidase A (MAO-A) or flavin-containing monooxygenase (FMO) was used to catalytically oxidize MM, and the oxygen consumption induced by this reaction was monitored. Coupled with this system, a substrate regeneration cycle with ascorbic acid was carried out. However, a sensor for the detection of $\mathrm{O}_{2}$ depletion, which has the initially high current background of the oxygen electrode [13], is less sensitive than one for $\mathrm{H}_{2} \mathrm{O}_{2}$ measurement. To solve this problem and seek sensitive detection methods, our objective was to develop a MM biosensor coupled with sensitive hydrogen peroxide detection. Alcohol oxidase (AOX) is known to catalytically oxidize MM with production of formaldehyde, sulfide and $\mathrm{H}_{2} \mathrm{O}_{2}[14]$ according to the reaction:

$$
\mathrm{H}_{3} \mathrm{C}-\mathrm{SH}+\mathrm{O}_{2}+\mathrm{H}_{2} \mathrm{O} \stackrel{[\text { AOX }]}{\longrightarrow} \mathrm{H}_{2} \mathrm{C}=\mathrm{O}+\mathrm{H}_{2} \mathrm{~S}+\mathrm{H}_{2} \mathrm{O}_{2}
$$

Hydrogen peroxide generated during enzyme-catalyzed reactions can be electrochemically detected on modified/unmodified carbon matrixes [15-27]. In this work, unmodified carbon nanotube (CNT), cobalt phthalocyanine (CoPC), Prussian blue (PB), and Os-wired HRP modified screen printed electrode (CSPE) sensors were fabricated and tested to detect $\mathrm{H}_{2} \mathrm{O}_{2}$. Our aim was to seek the most sensitive and optimal detection method of $\mathrm{H}_{2} \mathrm{O}_{2}$ for a $\mathrm{MM}$ amperometric biosensor.

\section{Experimental}

\subsection{Reagents}

Hydrogen peroxide $\left(\mathrm{H}_{2} \mathrm{O}_{2}, 30 \%\right.$, w/w), disodium hydrogen phosphate $\left(\mathrm{Na}_{2} \mathrm{HPO}_{4}\right)$, potassium chloride $(\mathrm{KCl})$, sodium chloride $(\mathrm{NaCl})$, acetic acid $\left(\mathrm{CH}_{3} \mathrm{COOH}\right)$, sodium acetate trihydrate $\left(\mathrm{CH}_{3} \mathrm{COONa} \cdot 3 \mathrm{H}_{2} \mathrm{O}\right)$, potassium hexacyanoferrate (III) $\left(\mathrm{K}_{3} \mathrm{Fe}(\mathrm{CN})_{6}\right)$, o-phenylenediamine $(99.5 \%)$, bovine serum albumin (BSA, $\geq 96 \%$ ) were obtained from Sigma-Aldrich (Lyon, France). The concentration of diluted $\mathrm{H}_{2} \mathrm{O}_{2}$ solutions was determined by the classic potassium permanganate titration method. Sulfuric acid (95\%) $\left(\mathrm{H}_{2} \mathrm{SO}_{4}\right)$ and $\mathrm{NaH}_{2} \mathrm{PO}_{4} \cdot 2 \mathrm{H}_{2} \mathrm{O}$ were purchased from Prolabo (Briare, France). Hydrochloric acid ( $\mathrm{HCl})$ (37\%) was obtained from Carlo Erba Reagenti (Milan, Italy). Peroxidase redox polymer (Os-wired HRP) was purchased from Bioanalytical Systems, Inc. (Gloucestershire, UK). Carbon pastes used for screen printed electrodes (Electrodag PE-410, 423SS and 6037SS) were obtained from Acheson (Plymouth, UK). A glycerolphtalic paint (Astral, France) was used as insulating layer. Transparent PVC sheets $(200 \mathrm{~mm} \times 100 \mathrm{~mm} \times 0.5 \mathrm{~mm})(\mathrm{SKK}$, Denzlingen, 
Germany) were used as screen-printing substrates. All chemicals were used without any further purification. All solutions were prepared using Milli-Q water.

\subsection{Instrument}

CSPEs were produced in the laboratory using a semi-automatic DEK 248 screen-printing system (DEK, Weymounth, UK). The working electrode was a $4 \mathrm{~mm}$ diameter disk, the auxiliary electrode was a $16 \mathrm{~mm} \times 1.5 \mathrm{~mm}$ curved wire and the $\mathrm{Ag} / \mathrm{AgCl}$ reference electrode was a $5 \mathrm{~mm} \times 1.5 \mathrm{~mm}$ straight wire (Figure 1).

Figure 1. Screen printed electrode.

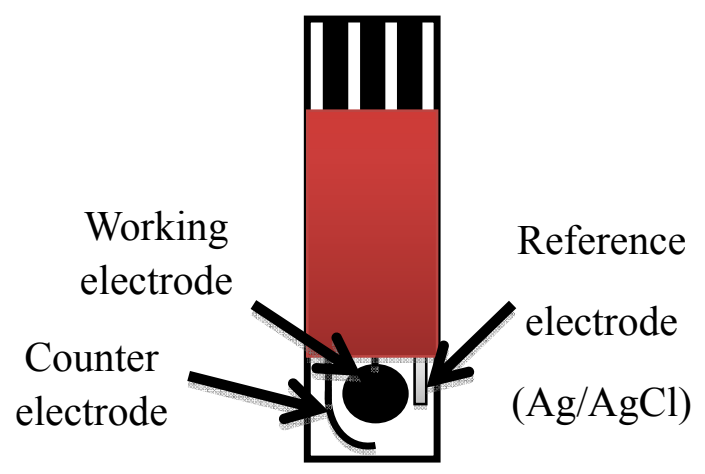

Cyclic voltammetry (CV) measurements, PB electrodeposition, PPD electropolymerisation and amperometric measurements were carried out on an AUTOLAB PGSTAT100 (Metrohm, Switzerland), using GPES v4.7 (Metrohm) as informatic interface. All potential values are reported versus $\mathrm{Ag} / \mathrm{AgCl}$. Amperometric measurements were performed in a $10 \mathrm{~mL}$ glass bath cell with magnetic stirring at room temperature.

\subsection{Carbon Screen Printed Electrode Modifications}

\subsubsection{Preparation of CNT Modified CSPEs}

CNT modified CSPEs were prepared as described in the work of Silveira et al. [28]. Briefly, $10 \mu \mathrm{L}$ of $0.3 \mathrm{mg} / \mathrm{mL}$ SWCNT water dispersion were successively deposited on the CSPEs working electrode, drying each layer one by one under vacuum. The electrodes were then washed with water.

\subsubsection{Preparation of CoPC Modified CSPEs}

Cobalt-phtalocyanine-modified paste was purchased from Gwent Electronic Materials, Ltd. (Gwent, UK) and modifications were performed on working electrode by the DEK screen-printing system.

\subsubsection{Preparation of PB/PPD Modified CSPEs}

The PB film was first deposited by covering the CSPEs with a solution containing $2.5 \mathrm{mM} \mathrm{FeCl}_{3}$, $2.5 \mathrm{mM} \mathrm{K}_{3} \mathrm{Fe}(\mathrm{CN})_{6}, 0.1 \mathrm{M} \mathrm{KCl}$ and $0.1 \mathrm{M} \mathrm{HCl}$ and applying a potential $+0.4 \mathrm{~V}$ versus $\mathrm{Ag} / \mathrm{AgCl}$ for $40 \mathrm{~s}$. Then the $\mathrm{PB}$ film was activated by covering the electrode by a solution containing $0.1 \mathrm{M} \mathrm{KCl}$ and $0.1 \mathrm{M}$ $\mathrm{HCl}$, electrochemically cycling for 20 cycles between $-0.05 \mathrm{~V}$ and $0.35 \mathrm{~V}$ versus $\mathrm{Ag} / \mathrm{AgCl}$ at a scan rate 
of $50 \mathrm{mV} \cdot \mathrm{s}^{-1}$. After washing with distilled water, it was dried for $1 \mathrm{~h}$ at $100{ }^{\circ} \mathrm{C}$ in oven. To improve the stability and selectivity properties of the PB electrodes, the electropolymerisation of a poly- (o-phenylenediamine) (PPD) coat was formed. The PPD layer was deposited by electrochemically cycling the $\mathrm{PB}$ modified electrode with potential between $-0.5 \mathrm{~V}$ and $0.7 \mathrm{~V}$ versus $\mathrm{Ag} / \mathrm{AgCl}$ at a scan rate of $50 \mathrm{mV} \cdot \mathrm{s}^{-1}$ in deaerated $0.1 \mathrm{M}, \mathrm{pH} 5.0$ acetate buffer solution containing $0.5 \mathrm{mM}$ $o$-phenylenediamine under a stream of nitrogen [29].

\subsubsection{Preparation of Os Wired HRP (Os-HRP) Modified CSPEs}

For the Os-HRP modified CSPEs, $10 \mu \mathrm{L} 0.1 \mathrm{M}$ phosphate buffer solution, $\mathrm{pH} 7.5$, containing 10\% $(\mathrm{v} / \mathrm{v})$ Os-HRP was deposited on the surface of CSPEs. It was allowed to dry at room temperature for $2 \mathrm{~h}$. It was thoroughly washed with buffer before use.

\section{Results and Discussion}

\section{1. $\mathrm{H}_{2} \mathrm{O}_{2}$ Detection with Unmodified CSPES}

The cyclic voltammetry studies were performed in $0.1 \mathrm{M}$ phosphate buffer solution, $\mathrm{pH} 7.5$ to investigate the CSPEs' electrochemical behavior (Figure 2). CSPEs showed no obvious peak in the absence of $\mathrm{H}_{2} \mathrm{O}_{2}$ in the potential range from $-0.2 \mathrm{~V} \sim 0.8 \mathrm{~V}$ versus $\mathrm{Ag} / \mathrm{AgCl}$. In the presence of $\mathrm{H}_{2} \mathrm{O}_{2}$, CSPEs started to perform current response at potential around $+0.3 \mathrm{~V}$ versus $\mathrm{Ag} / \mathrm{AgCl}$, indicating the onset potential of the $\mathrm{H}_{2} \mathrm{O}_{2}$ electrooxidation.

Figure 2. Cyclic voltammograms of CSPEs in $0.1 \mathrm{M}$ phosphate buffer solution, $\mathrm{pH} 7.5$ (a); in presence of $1 \mathrm{mM} \mathrm{H} \mathrm{O}_{2}$ (b). Scan rate $20 \mathrm{mV} \cdot \mathrm{s}^{-1}$.

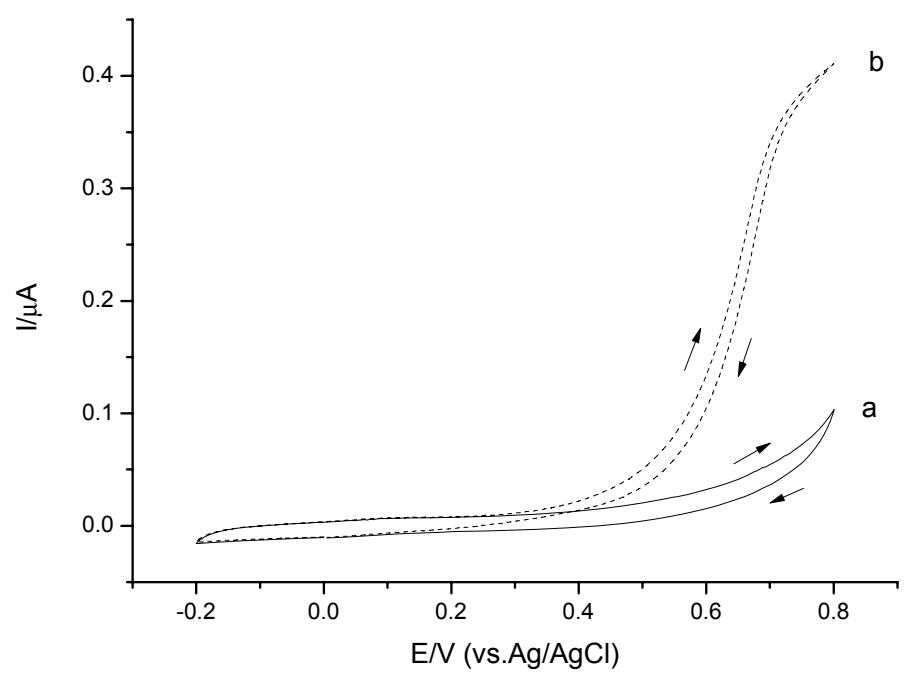

For the investigation of $\mathrm{H}_{2} \mathrm{O}_{2}$ limit detection, chronoamperometry experiments were carried out with several concentrations of $\mathrm{H}_{2} \mathrm{O}_{2}$ injected into the stirred bath cell (Figure 3). For unmodified CSPEs, the $\mathrm{H}_{2} \mathrm{O}_{2}$ detection limit was $3.1 \mu \mathrm{M}(\mathrm{S} / \mathrm{N}=3)$ applying a $+0.6 \mathrm{~V}$ potential versus $\mathrm{Ag} / \mathrm{AgCl}$, and the current response slope of the calibration curve was $0.208 \mu \mathrm{A} / \mathrm{mM}$. To investigate the reproducibility, three parallel measurements with $0.1 \mathrm{mM} \mathrm{H}_{2} \mathrm{O}_{2}$ revealed a relative standard deviation (RSD) of $12.1 \%$. The 
high RSD observed of unmodified CPSEs is likely related to the marked differences in the real active electrode area, which is difficult to handle and adjust.

Figure 3. Amperometric performance of CSPEs for detection of $\mathrm{H}_{2} \mathrm{O}_{2}$ at $+0.6 \mathrm{~V}$ in a stirred $0.1 \mathrm{M}$ phosphate buffer solution, $\mathrm{pH}$ 7.5. The upper left inset shows the calibration curve of CSPEs for $\mathrm{H}_{2} \mathrm{O}_{2}$ concentration; the lower right inset zooms in the part of the amperometric response of $5 \mu \mathrm{M} \mathrm{H}_{2} \mathrm{O}_{2}$ injected.

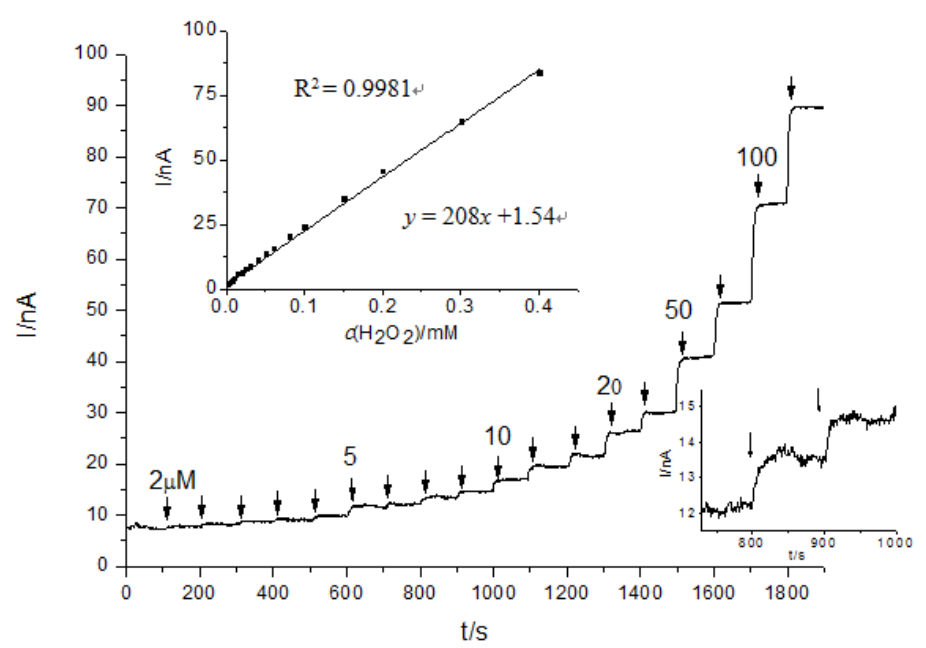

\section{2. $\mathrm{H}_{2} \mathrm{O}_{2}$ Detection with $\mathrm{CNT/CSPES}$}

Both CSPEs (Figure 2) and CNT/CSPEs (Figure 4) showed a $\mathrm{H}_{2} \mathrm{O}_{2}$ oxidation peak in the cyclic voltammetry experiments for the studied potential range. The onset potential of the $\mathrm{H}_{2} \mathrm{O}_{2}$ electrooxidation for CNT/CSPEs was around $+0.2 \mathrm{~V}$ versus $\mathrm{Ag} / \mathrm{AgCl}$, the detection limit was $1.3 \mu \mathrm{M}$ $(\mathrm{S} / \mathrm{N}=3)$ applying a positive potential of $+0.6 \mathrm{~V}$ versus $\mathrm{Ag} / \mathrm{AgCl}$, and the current response slope of CNT/CSPEs for $\mathrm{H}_{2} \mathrm{O}_{2}$ was $32.1 \mu \mathrm{A} / \mathrm{mM}$. To investigate the reproducibility, three parallel measurements with $0.1 \mathrm{mM} \mathrm{H}_{2} \mathrm{O}_{2}$ revealed a $\mathrm{RSD}$ of $19.7 \%$.

Figure 4. Cyclic voltammograms of CNT/CSPEs in $0.1 \mathrm{M}$ phosphate buffer solution, pH 7.5 (a); in presence of $1 \mathrm{mM} \mathrm{H} \mathrm{H}_{2} \mathrm{O}_{2}$ (b). Scan rate $20 \mathrm{mV} \cdot \mathrm{s}^{-1}$.

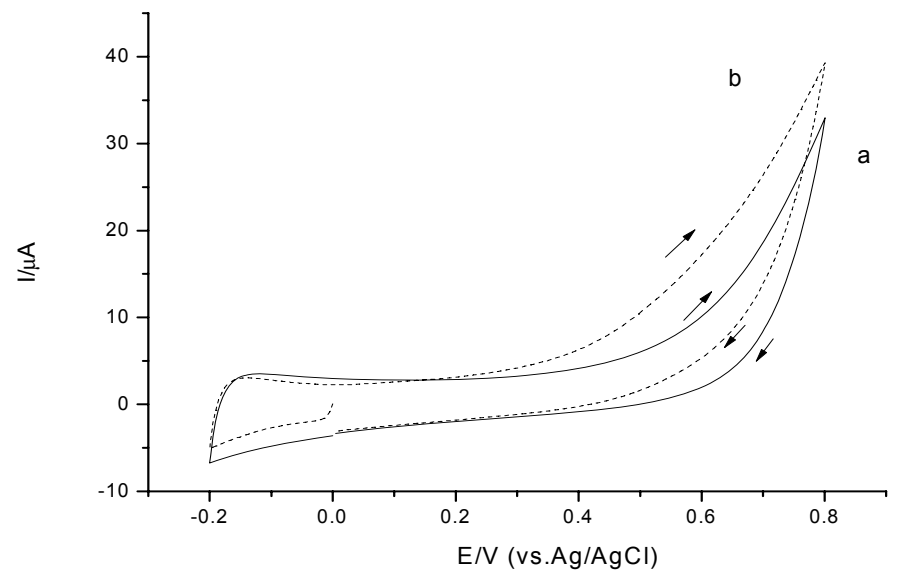


Both unmodified CSPEs and CNT are intrinsically carbon. Compared to unmodified CSPEs, detections of $\mathrm{H}_{2} \mathrm{O}_{2}$ for CNT/CSPEs need lower oxidation potential (CSPEs, $+0.3 \mathrm{~V}$; CNT/CSPEs, $+0.2 \mathrm{~V}$ ), and have lower detection limit (CSPEs, 3.1 $\mu \mathrm{M}$; CNT/CSPEs, $1.3 \mu \mathrm{M}$ ) with higher current response (CSPEs, $0.208 \mu \mathrm{A} / \mathrm{mM}$; CNT/CSPEs, $32.1 \mu \mathrm{A} / \mathrm{mM}$ ). The increased current response may arise from the large electric active area and a thin, porous diffusion layer [30]; the reasons of lower onset oxidation potential and lower detection limit are still controversial [31], because CNT may contain metal impurities derived from the catalysts used for their growth [32,33]. In a sense, CNT/CSPEs could be more favorable than unmodified CSPEs for $\mathrm{H}_{2} \mathrm{O}_{2}$ detection.

\section{3. $\mathrm{H}_{2} \mathrm{O}_{2}$ Detection with $\mathrm{CoPC} / \mathrm{CSPES}$}

To investigate the electrochemical behavior of CoPC/CSPEs in phosphate buffer solution, cyclic voltammetry experiments were carried out in the potential range of $-0.2 \mathrm{~V} \sim 0.8 \mathrm{~V}$ versus $\mathrm{Ag} / \mathrm{AgCl}$ (Figure 5). The presence of a well-defined oxidation current peak at around $+0.3 \mathrm{~V}$ versus $\mathrm{Ag} / \mathrm{AgCl}$ is consistent with the following reaction [21]:

$$
\begin{gathered}
2 \mathrm{Co}^{2+}+\mathrm{H}_{2} \mathrm{O}_{2} \rightarrow 2 \mathrm{Co}^{+}+\mathrm{O}_{2}+2 \mathrm{H}^{+} \\
2 \mathrm{Co}^{+} \rightarrow 2 \mathrm{Co}^{2+}+2 \mathrm{e}^{-}
\end{gathered}
$$

The reaction can be described by a chemical-electrochemical (CE) mechanism [21]: $\mathrm{H}_{2} \mathrm{O}_{2}$ chemically reduces $\mathrm{Co}^{2+}$ to $\mathrm{Co}^{+}$and its subsequent electrochemical re-oxidation is observed as an oxidation peak. Consequently, this peak is used for the quantification of $\mathrm{H}_{2} \mathrm{O}_{2}$. For CoPC/CSPEs, the $\mathrm{H}_{2} \mathrm{O}_{2}$ detection limit was calculated as $71 \mathrm{nM}(\mathrm{S} / \mathrm{N}=3)$ applying a positive potential of $+0.4 \mathrm{~V}$ versus $\mathrm{Ag} / \mathrm{AgCl}$ in chronoamperometry experiments, and the slope of the calibration curve was $3.7 \mu \mathrm{A} / \mathrm{mM}$ by. Three parallel measurements with $10 \mu \mathrm{M} \mathrm{H}_{2} \mathrm{O}_{2}$ reveal a RSD of $2.4 \%$, indicating a good reproducibility for this sensor.

Figure 5. Cyclic voltammograms of CoPC/CSPEs in $0.1 \mathrm{M}$ phosphate buffer solution, pH 7.5 (a); in presence of $0.1 \mathrm{mM} \mathrm{H}_{2} \mathrm{O}_{2}$ (b). Scan rate $20 \mathrm{mV} \cdot \mathrm{s}^{-1}$.

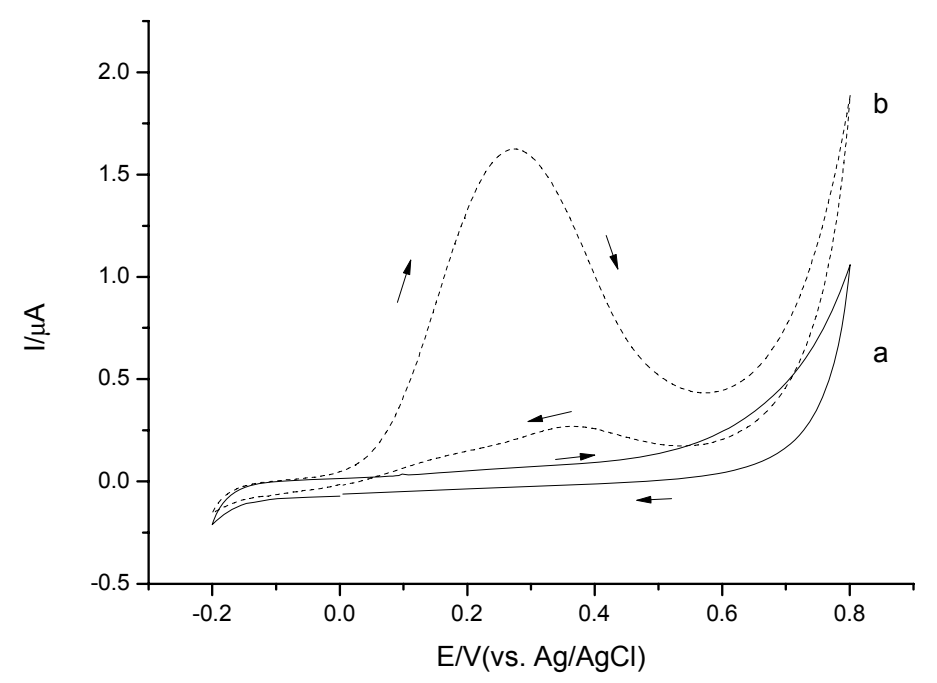




\section{4. $\mathrm{H}_{2} \mathrm{O}_{2}$ Detection with PPD/PB/CSPES}

$\mathrm{PB}$ is known to have a high solubility in neutral and basic solutions [34,35], consequently the PB-modified electrodes may have stability problems under our conditions. To improve the stability and selectivity of the PB electrodes a PPD coat is formed. In order to assess the effect of the PPD coat on the stability of the PB modified electrodes, cyclic voltammetry experiments were carried out in $0.1 \mathrm{M}$ phosphate buffer $\mathrm{pH} 7.5$ (not shown in this paper).

Without PPD layer coating, PB dissolved in solution, resulting in a CV current decrease in the scanning process. After 20 scan cycles, the PB/CSPEs CV's performance were similar to the unmodified CSPEs (Figure 2). With PPD layer coating, the response of redox peaks of PB reduced slightly even after 50 scan cycles, indicating that the PPD layer stabilized the PB. To investigate the electrochemical performance of PPD/PB/CSPEs $\mathrm{H}_{2} \mathrm{O}_{2}$ was added to the solution (Figure 6).

Figure 6. Cyclic voltammograms of $\mathrm{PPD} / \mathrm{PB} / \mathrm{CSPEs}$ in $0.1 \mathrm{M}$ phosphate buffer solution, pH 7.5 (a); in presence of $0.1 \mathrm{mM} \mathrm{H}_{2} \mathrm{O}_{2}$ (b) and $1 \mathrm{mM} \mathrm{H}_{2} \mathrm{O}_{2}$ (c). Scan rate $20 \mathrm{mV} \cdot \mathrm{s}^{-1}$.

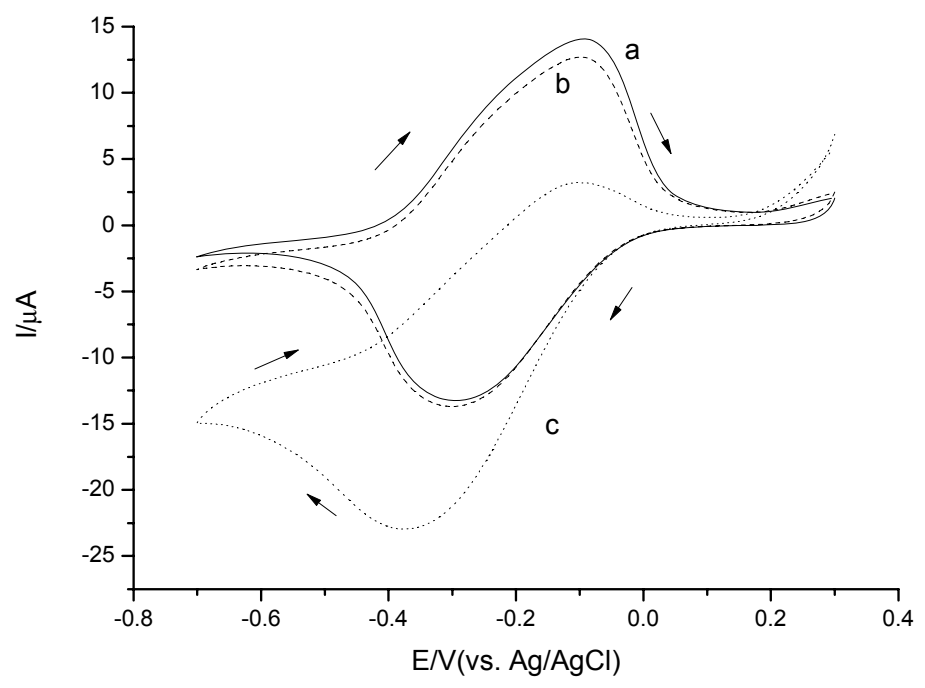

In the phosphate solution, the redox peaks correspond to the reduction of Prussian blue and oxidation of Prussian white as [36]:

$$
\begin{gathered}
\mathrm{Fe}_{4}{ }^{(\mathrm{III})}\left[\mathrm{Fe}^{(\mathrm{II})}(\mathrm{CN})_{6}\right]_{3}+\mathrm{K}^{+}+\mathrm{e}^{-} \leftrightarrow \mathrm{K}_{4} \mathrm{Fe}_{4}{ }^{(\mathrm{II})}\left[\mathrm{Fe}^{(\mathrm{III})}(\mathrm{CN})_{6}\right]_{3} \\
\text { Prussian blue } \\
\text { Prussian white }
\end{gathered}
$$

In the presence of $\mathrm{H}_{2} \mathrm{O}_{2}$, the electrocatalytical reductive reaction of $\mathrm{PB}$ towards to $\mathrm{H}_{2} \mathrm{O}_{2}$ can be described as:

$$
\begin{array}{cl}
\mathrm{K}_{4} \mathrm{Fe}_{4}{ }^{(\mathrm{II})}\left[\mathrm{Fe}^{(\mathrm{III})}(\mathrm{CN})_{6}\right]_{3}+\mathrm{H}_{2} \mathrm{O}_{2} \rightarrow \mathrm{Fe}_{4}{ }^{(\mathrm{III})}\left[\mathrm{Fe}^{(\mathrm{II})}(\mathrm{CN})_{6}\right]_{3}+\mathrm{K}^{+}+\mathrm{OH}^{-} \\
\text {Prussian white } & \text { Prussian blue }
\end{array}
$$

For PPD/PB/CSPEs, the $\mathrm{H}_{2} \mathrm{O}_{2}$ detection limit was $1.3 \mu \mathrm{M}(\mathrm{S} / \mathrm{N}=3)$ for a cathode potential of $-0.2 \mathrm{~V}$ and the current response slope was $-33 \mu \mathrm{A} / \mathrm{mM}$. Three parallel measurements with $10 \mu \mathrm{M} \mathrm{H}_{2} \mathrm{O}_{2}$ revealed a $\mathrm{RSD}=4.1 \%$. The lower RSDs observed of CoPC/CSPEs and PPD/PB/CSPEs than for unmodified CPSEs and CNT/CSPEs are likely related to the better control of mediator deposition. 


\section{5. $\mathrm{H}_{2} \mathrm{O}_{2}$ Detection with Os-HRP/CSPES}

The Os-HRP/CSPEs show a couple of stable and well-defined redox peaks at around $+30 \mathrm{mV}$ and $+70 \mathrm{mV}$ at a scan rate of $20 \mathrm{mV} \cdot \mathrm{s}^{-1}$ (Figure 7 curve a). In the presence of $\mathrm{H}_{2} \mathrm{O}_{2}$ (Figure 7 curve b), the electrocatalytical reductive reaction process of Os-HRP towards to $\mathrm{H}_{2} \mathrm{O}_{2}$ can be described by Scheme 1 .

Figure 7. Cyclic voltammograms of Os-HRP/CSPEs in $0.1 \mathrm{M}$ phosphate buffer solution, pH7.5 (a__ $)$; in presence of $0.1 \mathrm{mM} \mathrm{H}_{2} \mathrm{O}_{2}(\mathrm{~b}-----)$. Scan rate $20 \mathrm{mV} \cdot \mathrm{s}^{-1}$.

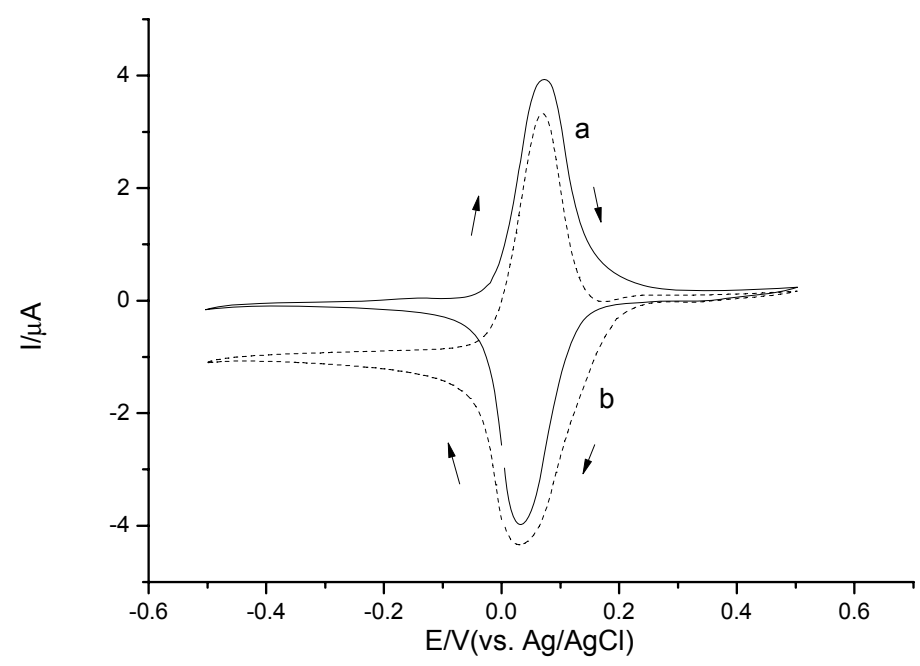

Scheme 1. The electrocatalytical reductive reaction process of Os-HRP towards $\mathrm{H}_{2} \mathrm{O}_{2}$.

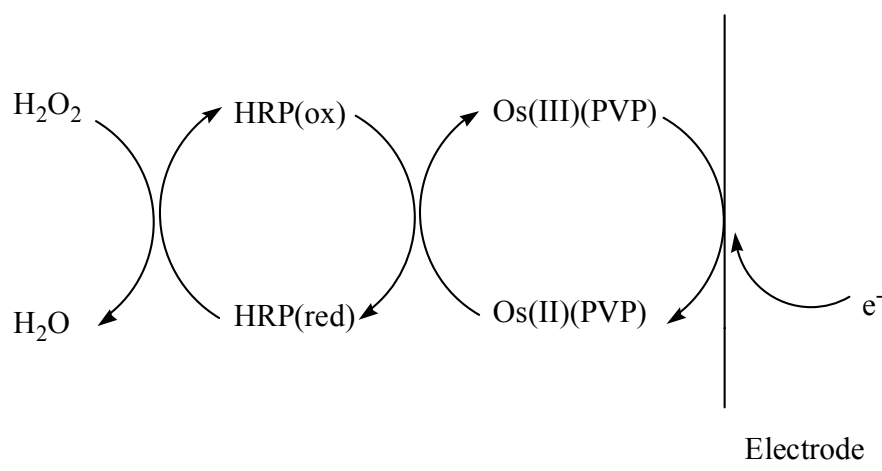

For Os-HRP/CSPEs, the $\mathrm{H}_{2} \mathrm{O}_{2}$ detection limit was $13.7 \mathrm{nM}(\mathrm{S} / \mathrm{N}=3)$ at a cathode potential $-0.1 \mathrm{~V}$ versus $\mathrm{Ag} / \mathrm{AgCl}$ (Figure 8). According to the Michaelis-Menten equation, the calculated apparent $\mathrm{K}_{\mathrm{M}, \mathrm{p}}$, from the curve fitting is $53.5 \mu \mathrm{M}$. This low $\mathrm{K}_{\mathrm{M}, \mathrm{p}}$ value indicates Os-HRP's high affinity and high effective conversion for the $\mathrm{H}_{2} \mathrm{O}_{2}$ substrate and a favorable electron-transfer rate with the osmium mediator. A linear range was obtained until $25 \mu \mathrm{M}$. Three parallel measurements with $1 \mu \mathrm{M} \mathrm{H}_{2} \mathrm{O}_{2}$ revealed a RSD of $1.3 \%$, which indicates a good reproducibility. This may be ascribed to the application of a low cathode potential to avoid the interferences with electro-active species. In addition, Os-HRP/CSPEs can be the most specific in detection of $\mathrm{H}_{2} \mathrm{O}_{2}$ because of the specificity of the reaction between $\mathrm{HRP}$ and $\mathrm{H}_{2} \mathrm{O}_{2}$. 
Figure 8. Amperometric performance of Os-HRP/CSPEs sensor in detection of $\mathrm{H}_{2} \mathrm{O}_{2}$ at $-0.1 \mathrm{~V}$ in a stirred $0.1 \mathrm{M}$ phosphate buffer solution, $\mathrm{pH}$ 7.5. The upper right inset shows the calibration curve of Os-HRP/CSPEs for $\mathrm{H}_{2} \mathrm{O}_{2}$ concentration; the lower left inset zooms in on the part of the amperometric response of $0.01 \mu \mathrm{M} \mathrm{H}_{2} \mathrm{O}_{2}$ injected.

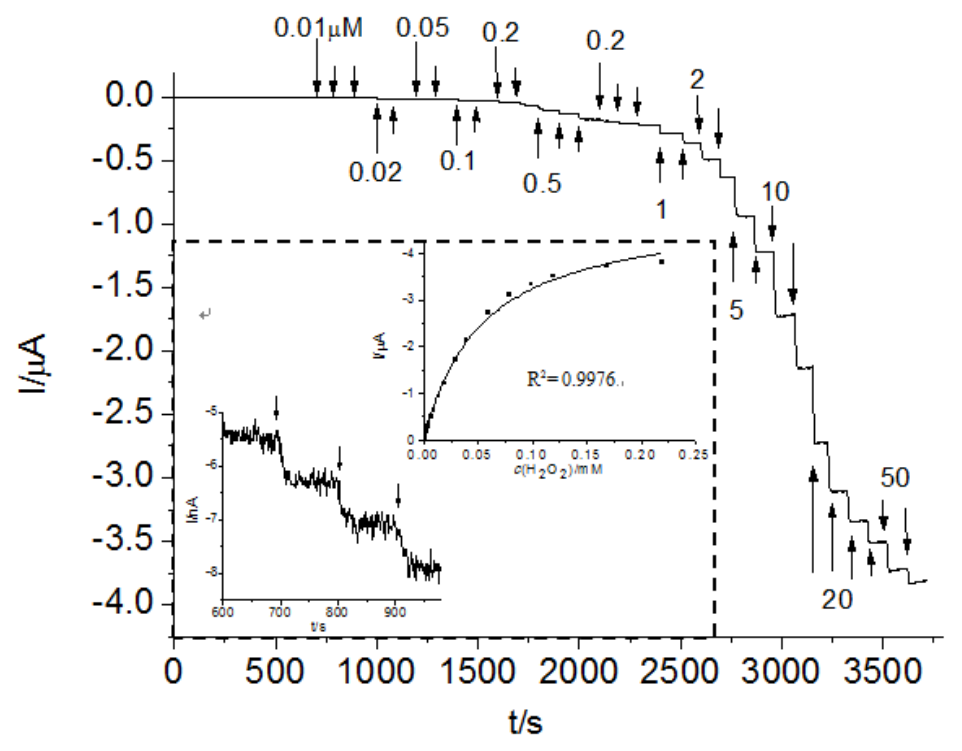

The comparison of the amperometric analytical behavior to $\mathrm{H}_{2} \mathrm{O}_{2}$ of the five kinds of electrodes developed in this study is summarized in Table 1. It shows that the Os-HRP/CSPEs are the most sensitive electrodes with a low reduction potential applied for $\mathrm{H}_{2} \mathrm{O}_{2}$ detection. This is due to the specific, sensitive and rapid turnover of Os- $\mathrm{HRP}$ to $\mathrm{H}_{2} \mathrm{O}_{2}$.

Table 1. Comparison of the amperometric analytical performances for $\mathrm{H}_{2} \mathrm{O}_{2}$ detection with the five kinds of electrodes prepared in the present work.

\begin{tabular}{cccc}
\hline Type of Electrodes & Potential Applied $(\mathbf{V})$ & LOD $(\mathbf{S} / \mathbf{N}=\mathbf{3})$ & RSD $\left(\right.$ Tested Concentration of $\left.\mathbf{H}_{2} \mathbf{O}_{2}\right)$ \\
\hline CSPEs & +0.6 & $3.1 \mu \mathrm{M}$ & $12.1 \%(0.1 \mathrm{mM})$ \\
CNT/CSPEs & +0.6 & $1.3 \mu \mathrm{M}$ & $19.7 \%(0.1 \mathrm{mM})$ \\
CoPC/CSPEs & +0.4 & $71 \mathrm{nM}$ & $2.4 \%(10 \mu \mathrm{M})$ \\
PPD/PB/CSPEs & -0.2 & $1.3 \mu \mathrm{M}$ & $4.1 \%(10 \mu \mathrm{M})$ \\
Os-HRP/CSPEs & -0.1 & $13.7 \mathrm{nM}$ & $1.3 \%(1 \mu \mathrm{M})$ \\
\hline
\end{tabular}

Interference of electro-active species [25,37-39] is often encountered when using amperometric biosensors and applying a high potential in real samples. The decrease of the applied potential can be effective to avoid a lot of electrochemical interferences. With this consideration, PPD/PB/CSPEs and Os-HRP/CSPEs are used to combine with alcohol oxidase (AOX) in bovine serum albumin matrix to detect methyl mercaptan (MM) applying a low potential in the aqueous phase. The limit of detection of $\mathrm{AOX} / \mathrm{PPD} / \mathrm{PB} / \mathrm{CSPEs}$ to $\mathrm{MM}$ is $10 \mu \mathrm{M}$; of AOX/Os-HRP/CSPEs to $\mathrm{MM}$ is $0.5 \mu \mathrm{M}$. For AOX/Os-HRP/CSPEs, the calibration curve of the response to MM is linear in the concentration range $0 \sim 15 \mu \mathrm{M}$ with a good correlation with the classical analytical method. We are working on the stability of the biosensor which is the crucial point to improve its accuracy and reliability. Consequently, Os-HRP/CSPEs are combined with alcohol oxidase an optimum method which gives the best sensitivity in methyl mercaptan detection. 


\section{Conclusions}

Five kinds of modified carbon screen printed electrodes applied for $\mathrm{H}_{2} \mathrm{O}_{2}$ amperometric detection for MM biosensors were presented in this work. In comparison, and despite a worse reproducibility, CNT/CSPEs are a better choice than unmodified CPSEs in $\mathrm{H}_{2} \mathrm{O}_{2}$ detection resulting from their lowest detection limit, lowest onset oxidation potential and highest current response of CNT/CSPEs. However, the applied potential of $+0.6 \mathrm{~V}$ versus $\mathrm{Ag} / \mathrm{AgCl}$ is too positive to avoid the interference of electro-active species. CoPC/CSPEs and PPD/PB/CSPEs are also a good choice in $\mathrm{H}_{2} \mathrm{O}_{2}$ detection because of their low applied potential, low detection limit and good reproducibility. Os-HRP/CSPEs display the lowest detection limit and the best operational reproducibility towards $\mathrm{H}_{2} \mathrm{O}_{2}$. With the cathode potential applied and the use of HRP, Os-HRP/CSPEs can avoid the interference of electro-active species and be specific for $\mathrm{H}_{2} \mathrm{O}_{2}$ detection. The Os-wired HRP modified screen printed electrode is the optimum method we used to combine with alcohol oxidase in a methyl mercaptan biosensor, usable in both aqueous and gaseous phase detection.

\section{Acknowledgements}

Zhan-Hong Li thanks China Scholarship Council (CSC) for his financial support.

\section{References}

1. Tonzetich, J.; Carpenter, P.A. Production of volatile sulphur compounds from cysteine, cystine and methionine by human dental plague. Arch. Oral Biol. 1971, 16, 599-607.

2. Tonzetich, J. Production and origin of oral malodor: A review of mechanisms and methods of analysis. J. Periodontol. 1977, 48, 13-20.

3. Awano, S.; Koshimune, S.; Kurihara, E.; Gohara, K.; Sakai, A.; Soh, I.; Hamasaki, T.; Ansai, T.; Takehara, T. The assessment of methyl mercaptan, an important clinical marker for the diagnosis of oral malodor. J. Dent. 2004, 32, 555-559.

4. Ugliano, M.; Kwiatkowski, M.; Vidal, S.P.; Capone, D.; Siebert, T.; Dieval, J.-B.; Aagaard, O.; Waters, E.J. Evolution of 3-Mercaptohexanol, Hydrogen Sulfide, and Methyl Mercaptan during bottle storage of sauvignon blanc wines. Effect of glutathione, copper, oxygen exposure, and closure-derived oxygen. J. Agric. Food Chem. 2011, 59, 2564-2572.

5. ATSDR. Toxicological Profile for Methyl Mercaptan; Agency for Toxic Substances and Disease Registry (ATSDR) US Public Health Service: Atlanta, GA, USA, 1992.

6. Bates, T.S.; Lamb, B.K.; Guenther, A.; Dignon, J.; Stoiber, R.E. Sulfur emissions to the atmosphere from natural sources. J. Atmos. Chem. 1992, 14, 315-337.

7. Rosenberg, M.; Kulkarni, G.V.; Bosy, A.; McCulloch, C.A. Reproducibility and sensitivity of oral malodor measurements with a portable sulphide monitor. J. Dent. Res. 1991, 70, 1436-1440.

8. Rosenberg, M.; Septon, I.; Eli, I.; Bar-Ness, R.; Gelernter, I.; Brenner, S.; Gabbay, J. Halitosis measurement by an industrial sulphide monitor. J. Periodontol. 1991, 62, 487-489.

9. Mitsubayashi, K.; Hashimoto, Y. Bioelectronic nose for methyl mercaptan vapor using xenobiotic metabolizing enzyme: Flavin-containing monooxygenase. Sens. Actuators B Chem. 2002, 83, 35-40. 
10. Minamide, T.; Mitsubayashi, K.; Jaffrezic-Renault, N.; Hibi, K.; Endo, H.; Saito, H. Bioelectronic detector with monoamine oxidase for halitosis monitoring. Analyst 2005, 130, 1490-1494.

11. Minamide, T.; Mitsubayashi, K.; Saito, H. Bioelectronic sniffer with monoamine oxidase for methyl mercaptan vapor. Sens. Actuators B Chem. 2005, 108, 639-645.

12. Mitsubayashi, K.; Minamide, T.; Otsuka, K.; Kudo, H.; Saito, H. Optical bio-sniffer for methyl mercaptan in halitosis. Anal. Chim. Acta 2006, 573, 75-80.

13. Blum, L.J.; Coulet, P.R. Biosensor Principles and Applications; Marcel Dekker, Inc.: New York, NY, USA, 1991.

14. Suylen, G.M.H.; Large, P.J.; Dijken, J.P.V.; Kuenen, J.G. Methyl mercaptan oxidase, a key enzyme in the metabolism of methylated sulphur compounds by hyphomicvobium EG. J. Gen. Microbiol. 1987, 133, 2989-2997.

15. Wang, J.; Musameh, M.; Lin, Y. Solubilization of carbon nanotubes by nafion toward the preparation of amperometric biosensors. J. Am. Chem. Soc. 2003, 125, 2408-2409.

16. Trojanowicz, M. Analytical applications of carbon nanotubes: A review, trac-trend. Anal. Chem. 2006, 25, 480-489.

17. Wang, J.; Musameh, M. Carbon nanotube/teflon composite electrochemical sensors and biosensors. Anal. Chem. 2003, 75, 2075-2079.

18. Wang, J. Carbon-nanotube based electrochemical biosensors: A review. Electroanal 2005, 17, $7-14$.

19. Wang, J.; Golden, T.; Li, R. Cobalt phthalocyanine/cellulose acetate chemically modified electrodes for electrochemical detection in flowing streams. Multifunctional operation based upon the coupling of electrocatalysis and permselectivity. Anal. Chem. 1988, 60, 1642-1645.

20. Salimi, A.; Hallaj, R.; Soltanian, S.; Mamkhezri, H. Nanomolar detection of hydrogen peroxide on glassy carbon electrode modified with electrodeposited cobalt oxide nanoparticles. Anal. Chim. Acta 2007, 594, 24-31.

21. Gilmartin, M.A.T.; Hart, J.P.; Birch, B.J. Development of amperometric sensors for uric acid based on chemically modified graphite-epoxy resin and screen-printed electrodes containing cobalt phthalocyanine. Analyst 1994, 119,243-252.

22. Gilmartin, M.A.T.; Ewen, R.J.; Hart, J.P.; Honeybourne, C.L. Voltammetric and photoelectron spectral elucidation of the electrocatalytic oxidation of hydrogen peroxide at screen-printed carbon electrodes chemically modified with cobalt phthalocyanine. Electroanal 1995, 7, 547-555.

23. Ricci, F. Prussian Blue and enzyme bulk-modified screen-printed electrodes for hydrogen peroxide and glucose determination with improved storage and operational stability. Anal. Chim. Acta 2003, 485, 111-120.

24. Ricci, F.; Amine, A.; Palleschi, G.; Moscone, D. Prussian Blue based screen printed biosensors with improved characteristics of long-term lifetime and $\mathrm{pH}$ stability. Biosens. Bioelectron. 2003, 18, 165-174.

25. Ricci, F.; Palleschi, G. Sensor and biosensor preparation, optimisation and applications of Prussian Blue modified electrodes. Biosens. Bioelectron. 2005, 21, 389-407.

26. Garguilo, M.G.; Nhan, H.; Proctor, A.; Michael, A.C. Amperometric sensors for peroxide, choline, and acetylcholine based on electron transfer between horseradish peroxidase and a redox polymer. Anal. Chem. 1993, 65, 523-528. 
27. Vreeke, M.; Maidan, R.; Heller, A. Hydrogen peroxide and .beta.-nicotinamide adenine dinucleotide sensing amperometric electrodes based on electrical connection of horseradish peroxidase redox centers to electrodes through a three-dimensional electron relaying polymer network. Anal. Chem. 1992, 64, 3084-3090.

28. Silveira, C.M.; Baur, J.; Holzinger, M.; Moura, J.J.G.; Cosnier, S.; Almeida, M.G. Enhanced direct electron transfer of a multihemic nitrite reductase on single-walled carbon nanotube modified electrodes. Electroanal 2010, 22, 2973-2978.

29. Lobo, M.J.; Miranda, A.J.; Tipez-Fonseca, J.M.; Tuih, P. Electrocatalytic detection of nicotinamide coenzymes by poly(o-aminophenol)- and poly(o-phenylenediamine)-modified carbon paste electrodes. Anal. Chim. Acta 1996, 325, 33-42.

30. Scott, C.L.; Pumera, M. Carbon nanotubes can exhibit negative effects in electroanalysis due to presence of nanographite impurities. Electrochem. Commun. 2011, 13, 426-428.

31. Yang, W.; Ratinac, K.R.; Ringer, S.P.; Thordarson, P.; Gooding, J.J.; Braet, F. Carbon nanomaterials in biosensors: Should you use nanotubes or graphene? Angew. Chem. Int. Edit. 2010, 49, 2114-2138.

32. Šljukić, B.; Banks, C.E.; Compton, R.G. Iron oxide particles are the active sites for hydrogen peroxide sensing at multiwalled carbon nanotube modified electrodes. Nano Lett. 2006, 6, 1556-1558.

33. Banks, C.E.; Crossley, A.; Salter, C.; Wilkins, S.J.; Compton, R.G. Carbon nanotubes contain metal impurities which are responsible for the "electrocatalysis" seen at some nanotube-modified electrodes. Angew. Chem. Int. Edit. 2006, 45, 2533-2537.

34. Feldman, B.J.; Murray, R.W. Electron diffusion in wet and dry Prussian blue films on interdigitated array electrodes. Inorg. Chem. 1987, 26, 1702-1708.

35. Stilwell, D.E.; Park, K.H.; Miles, M.H. Electrochemical studies of the factors influencing the cycle stability of Prussian Blue films. J. Appl. Electrochem. 1992, 22, 325-331.

36. Haghighi, B.; Hamidi, H.; Gorton, L. Electrochemical behavior and application of Prussian Blue nanoparticle modified graphite electrode. Sens. Actuators B Chem. 2010, 147, 270-276.

37. Palmisano, F.; Zambonin, P.G. Ascorbic acid interferences in hydrogen peroxide detecting biosensors based on electrochemically immobilized enzymes. Anal. Chem. 1993, 65, 2690-2692.

38. Yamamoto, K.; Ohgaru, T.; Torimura, M.; Kinoshita, H.; Kano, K.; Ikeda, T. Highly-sensitive flow injection determination of hydrogen peroxide with a peroxidase-immobilized electrode and its application to clinical chemistry. Anal. Chim. Acta 2000, 406, 201-207.

39. Palleschi, G.; Ali Nabi Rahni, M.; Lubrano, G.J.; Ngwainbi, J.N.; Guilbault, G.G. A study of interferences in glucose measurements in blood by hydrogen peroxide based glucose probes. Anal. Biochem. 1986, 159, 114-121.

(C) 2013 by the authors; licensee MDPI, Basel, Switzerland. This article is an open access article distributed under the terms and conditions of the Creative Commons Attribution license (http://creativecommons.org/licenses/by/3.0/). 